\title{
THE APPLICATION OF TYPOLOGY METHOD IN HISTORICAL BUILDING INFORMATION MODELLING (HBIM) TAKING THE INFORMATION SURVEYING AND MAPPING OF JIAYUGUAN FORTRESS TOWN AS AN EXAMPLE
}

\author{
D.Y. Li a, K. Li b, C. Wu a, \\ ${ }^{a}$ Institute of Architectural History \& Theory, Tianjin University, Tianjin, China - 790806480@qq.com \\ ${ }^{b}$ Research Institute of Cultural Heritage, Tianjin University Research Institute of Architectural Design \& Urban Planning, Tianjin, \\ China-414395112@qq.com
}

KEY WORDS: Historical Building Information Modelling(HBIM), Typology, Jiayuguan, Revit Family Library, Age Identification

\begin{abstract}
:
With the promotion of fine degree of the heritage building surveying and mapping, building information modelling technology(BIM) begins to be used in surveying and mapping, renovation, recording and research of heritage building, called historical building information modelling(HBIM).

The hierarchical frameworks of parametric component library of BIM, belonging to the same type with the same parameters, has the same internal logic with archaeological typology which is more and more popular in the age identification of ancient buildings. Compared with the common materials, 2D drawings and photos, typology with HBIM has two advantages_- (1) comprehensive building information both in collection and representation and (2) uniform and reasonable classification criteria

This paper will take the information surveying and mapping of Jiayuguan Fortress Town as an example to introduce the field work method of information surveying and mapping based on HBIM technology and the construction of Revit family library.And then in order to prove the feasibility and advantage of HBIM technology used in typology method, this paper will identify the age of Guanghua gate tower, Rouyuan gate tower, Wenchang pavilion and the theater building of Jiayuguan Fortress Town with HBIM technology and typology method.
\end{abstract}

\section{INTRODUCTION}

The age identification of ancient buildings is always the important part of architectural archaeology, architectural history research and architecture history value judgement, and the basic work of further researches. Archaeological typology method, introduced from palaeontology, was used in the age identification of ancient building very early and it is more and more popular recently. But in this method, the traditional 2D drawings of surveying and mapping and photos, as the judge reference materials, cannot collect all the architectural information and exhibit all the architectural style, meanwhile the judge criteria are also different and unreasonable. So many age identification conclusions are overthrown in recent years. Though the specific methods and procedures have been modified perfect incessantly, the defect of these 2D drawings and photos cannot be avoided. And HBIM technology can solve these problems perfectly. As to HBIM, the full name of which is Historic Building Information Modelling, the concept was first raised by Maurice Murphy and Eugene McGovern from Ireland in 2009 ${ }^{1}$, and they raise the level of BIM technology application in architectural heritage to component hierarchy and formulate the protection measures based on it. In the same year, BIM technology was used to be responsible for structure simulation and economic evaluation and analysis in the restoration project of St. Maria of Collemaggio in L'Aquila of Italy. ${ }^{2}$ In China, the first case of the

\footnotetext{
${ }^{1}$ Maurice Murphy, Eugene McGovern, Sara Pavia . Historic building information modelling (HBIM) $[\mathrm{J}]$. Structural Survey . 2009,27 ( 4) : 311-327.

2 S. Logothetis, A. Delinasiou, E. Stylianidis . Building information modelling for cultural heritage: a review. 25th
}

BIM technology application occurred at the Forbidden City that a Chinese ancient architecture 3D model of a wing room was created by Revit. And from that time, the teachers and students of Tianjin University started to use BIM technology in Ta Keo Temple in Angkor Wat of Cambodia, Dehe Palace in the Summer Palace in Beijing and the Great Buddha Temple in Zhangye of China, and gradually found and summed up the age identification method with the combination of archaeological typology.

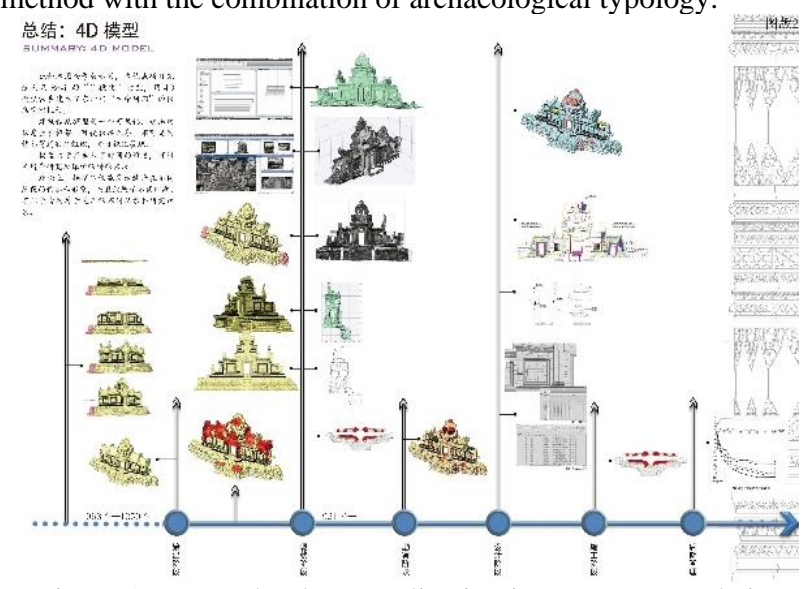

Figure.1 BIM technology application in Ta Keo Temple in Angkor Wat of Cambodia by Tianjin University ${ }^{3}$

International CIPA Symposium 2015, 31 August to 04 September 2015, Taipei, Taiwan

${ }^{3}$ WU C, WU S, LIU F, et al. Application of BIM on Angkor Monuments : A Case Study on Documentation and Research of the South Outer Gopura in Ta Keo Temple, Angkor 

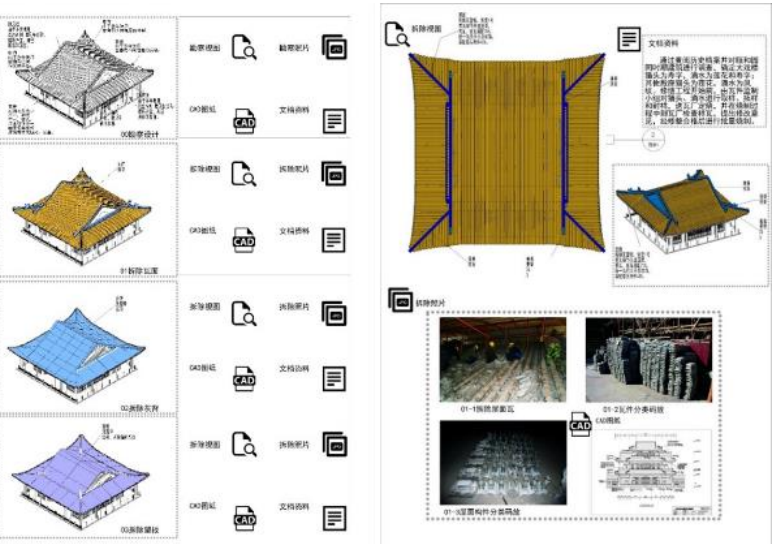

Figure.2 BIM technology application in Dehe Palace in the Summer Palace in Beijing by Tianjin University ${ }^{4}$

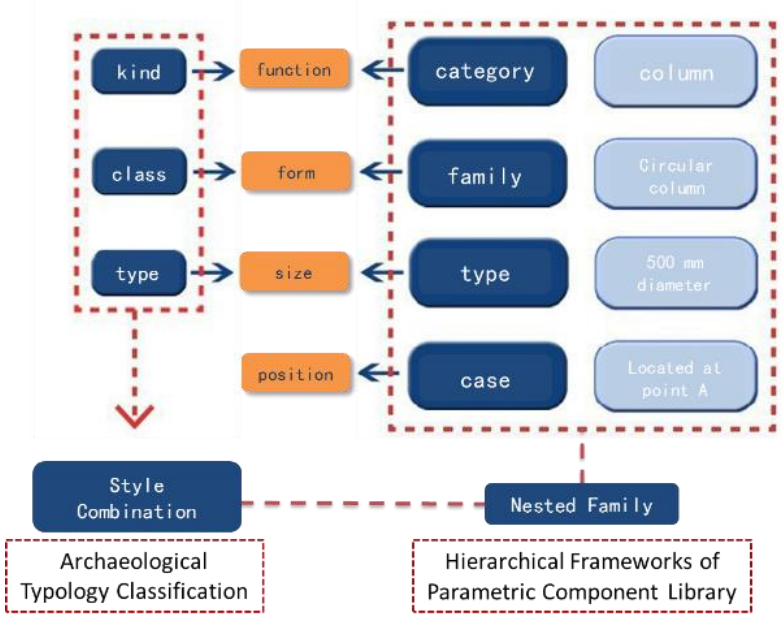

Figure.3 hierarchical frameworks of parametric component library \& archaeological typology classification

HBIM technology has a clear advantage in architectural heritage information collection and records. And Revit series software under BIM platform put forward a way of thinking according to structure logic so that typology analysis of the components is carried throughout all the procession of surveying and mapping, which overcomes the very possible disadvantages such as incomprehensive collection in traditional 2D-output oriented surveying and mapping. So this HBIM technology has the same inner logic with archaeological typology.

\section{STRUCTURE-AND-TYPE METHOD 5}

The route map of the "structure-and-type method" could be summarized as follows:

(1) to survey a building in 3D based on typological methodused in archaeology, Revit family system, and tectonic logic of buildings, taking each component or part as a unit;

(2) to draw a "space-structure dendrogram" (abbreviated as "structure tree") and "component type dendrogram" (abbreviated as "type tree");

Monuments $[\mathrm{M}]$. East Asian Architectural Culture International Conference, 12 to 14 May 2011. Singapore;

${ }^{4}$ Li Shujing. A Preliminary Research about Informatization Survey and Measurement of Historical Buildings based on BIM Technology under the Background of Informatization Survey and Measurement. Doctoral dissertation, 2014, Tianjin University.
(3) to make sketches and take survey notes based on the structure tree, and use both of them to reinforce understanding and support data capture and BIM modelling.

The structure tree, through locating each component in its "stratification", reflects structure, articulation, and space relation between components. The type tree, omitting space relations of components, mainly reflects typological relation between components, and essentially is an induction of dispersive components according to their shape and size, etc.

The structure tree is no longer limited to $2 \mathrm{D}$ drawings, resulting in a good understanding of tectonic logic of buildings. And the type tree can be drew out after vertical and horizontal comparison of similar components, which can help research construction style, age, regional inherited characteristics in a higher level. The investigation method mentioned above with the structure tree and the type tree regarded as core, is just the structure-and-type method.
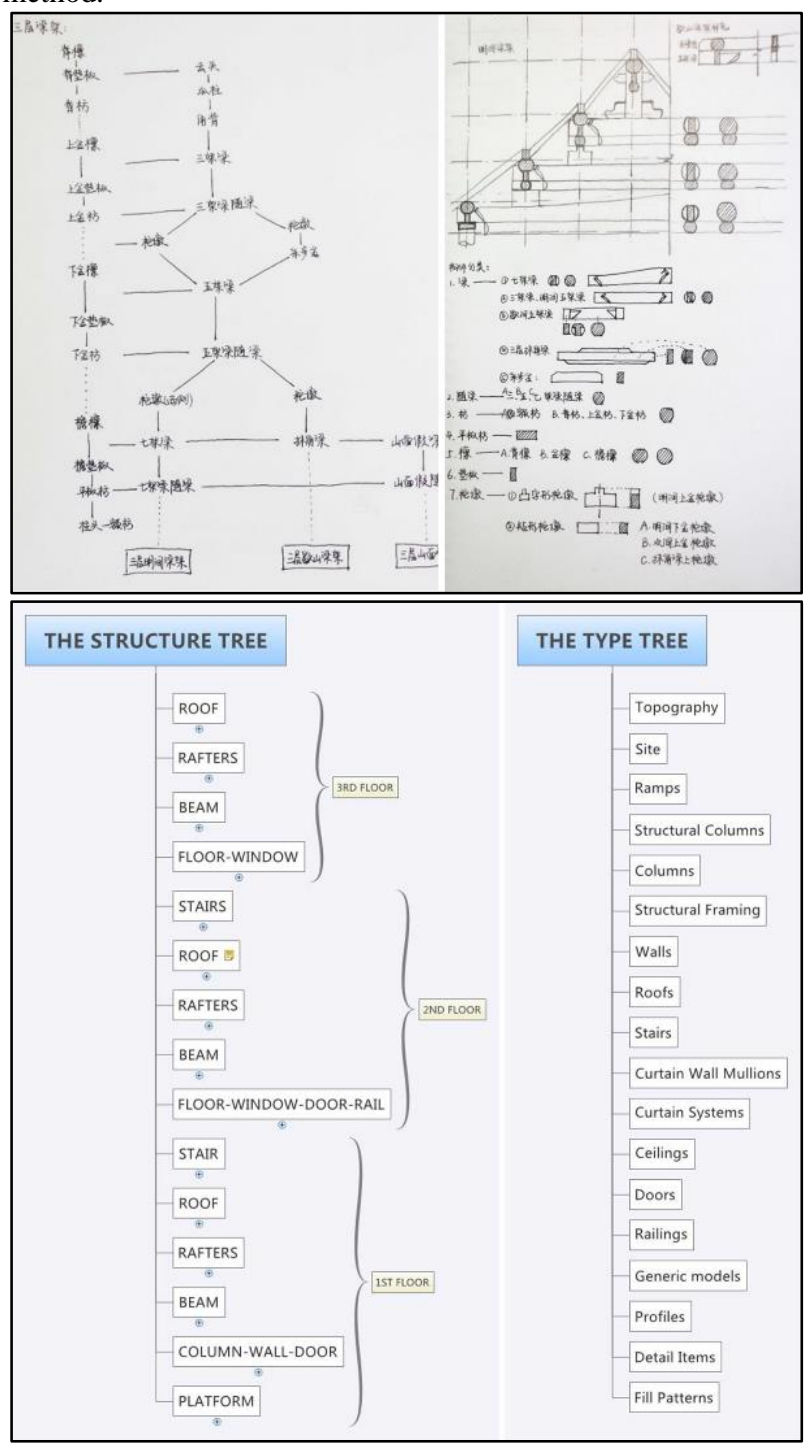

Figure. 4 the structure and type tree and sketches of field research

${ }^{5}$ K.Li, S.J.Li, Y.LIU, W.Wang, C.Wu. Coordination between Understanding Historic Buildings and BIM Modelling: A 3DOutput Oriented and typological Data Capture Method.[C]. 25th International CIPA Symposium 2015, 31 August-04 September 2015, Taipei, Taiwan. 


\section{ADVANTAGES OVER TRADITIONS}

To begin investigation with structure-and-type method, there will be a complete and accurate family library. For each single family, the selection of its family templates, the modelling approaches and parameters settings are all based on the analysis of the geometric and technology characteristics. So, the process of modelling is also a process of components information management. Different families come from different modelling processes, and different modelling processes prove the correctness of family classification, which has the same inner logic with typology method.

However, the target achievements of the traditional surveying and mapping are 2D oriented drawings and photos, the collection process of which is casual and heavily 2D oriented without typological thought. And researchers need to search related contents from these unorganized drawings and photos for further typology researches. Researches spend more time on recollection and get a set of data without guaranteed integrity and accuracy. And the further researches are away from the process of surveying and mapping, more from architectural image and less from architectural logic.

So, compared with the traditional 2D oriented achievements, HBIM-based investigation method has two main advantages:

$>$ Comprehensive building information

(1) Comprehensive collection

With the idea that 2D drawings is not the target of building surveying and mapping but the information building model, the new field work method will be focus on all the components and data not only the ones displayed on the drawings.

(2) Comprehensive representation

The pattern of 2D drawings can't show all the information of the building surveying and mapping, even if you have get all the information. And you can get all the information on BIM from any visual angles.

> Uniform and reasonable classification criteria

When you take building typology research, there will be different classification criteria for even the same components, and the uncomprehensive information and non-architecture logic are the main reason. The building model of BIM will provide both and the classification criteria will be uniform and reasonable.

\section{THE APPLICATION OF TYPOLOGY METHOD IN HBIM}

Based on the structure-and-type method above, the 4 ancient buildings of Jiayuguan Fortress Town, Guanghua Building, Rouyuan Building, Stage Building and Wenchang Pavilion was surveyed and mapped in 2014. Jiayuguan Fortress Town is in the $6 \mathrm{~km}$ southeast of Jiayuguan City, Gansu Province. According to the ancient literature and former researches, the exact age of these ancient buildings is not clear. In ancient time and Chinese ancient architecture's geographical distribution, the ancient buildings belong to Hexi (Corridor) Architecture System. So according to the archaeological typology method, the timber structure system of 16 ancient buildings in the Hexi Corridor Area, the age of which was clear according to the trace on the scene and related literature, has been modelled by Autodesk Revit. Then three style combinations of timber structure system of these buildings, the post-and-post pedestal combination under the ridge purlin, the inner purlin-and-cushion board-and-longitudinal tie-beam combination and beam-and-tie beam combination, which reflect the characteristics of the style change over time sharply, are studied into different staging results. Comparing the three style combinations of the 4 buildings of Jiayuguan Fortress Town with the staging results and corresponding the historical documentations, the age of these

\subsection{Style Combination Characteristics}

\subsubsection{The Post-And-Post Pedestal Combination Under The Ridge Purlin Combination}

The post-and-post pedestal combination under the ridge purlin combination is the component or component combination over the three-purlin beam and under the ridge purlin. The typical forms of this combination are the post-and-panjian dougong combination of the Yingzao Fashi and the post pedestal-and-post combination which is popular around the official-style buildings in the north China in the Qing dynasty. Different from the two types above, this combination in the Hexi Corridor Area can be divided 2 main types: the first one called Separation Type (hereinafter referred to as A type) and the second one called Integrity Type (hereinafter referred to as B type).

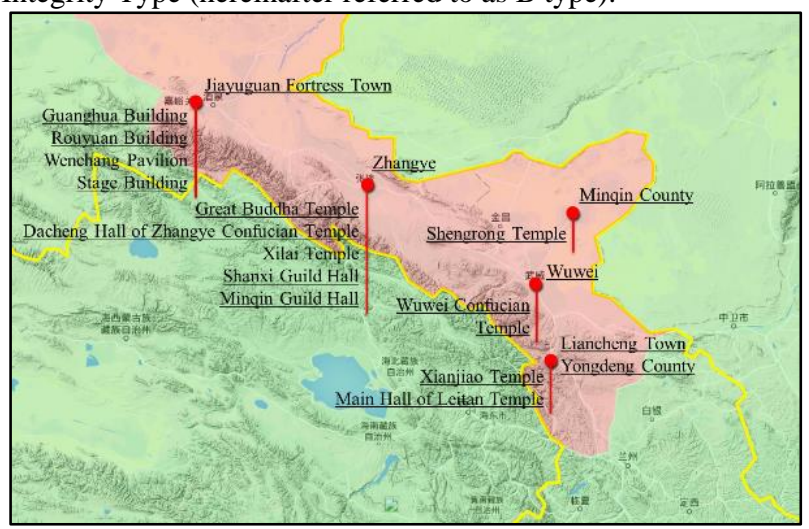

Figure.5 main Chinese ancient buildings in Hexi Corridor Area

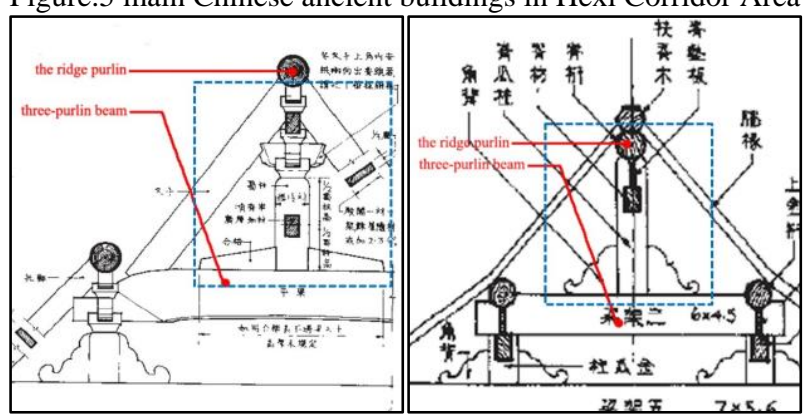

Figure.6 the post-and-panjian dougong combination(left) and the post pedestal-and-post combination(right)

Table. 1 types of the post-and-post pedestal combination under the ridge purlin (C1 hereinafter)

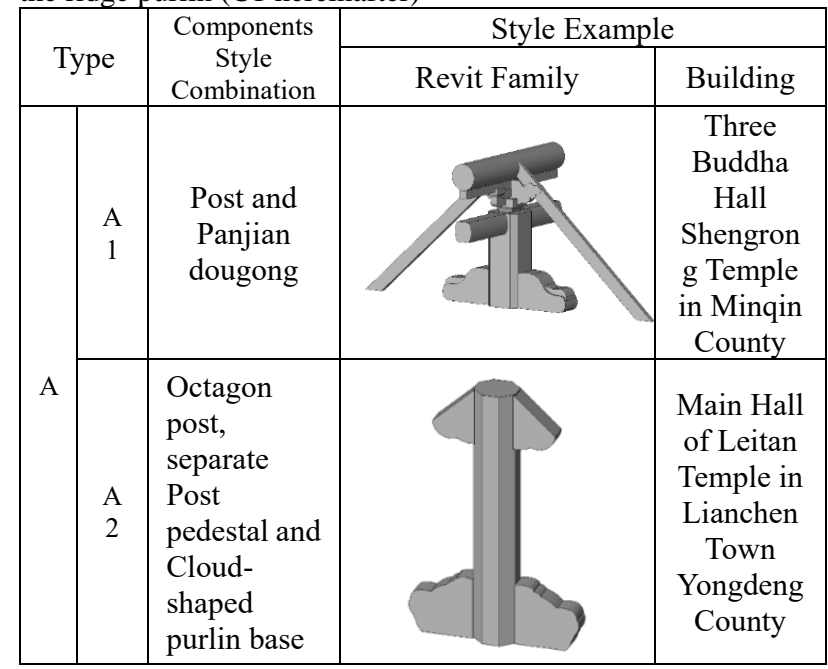




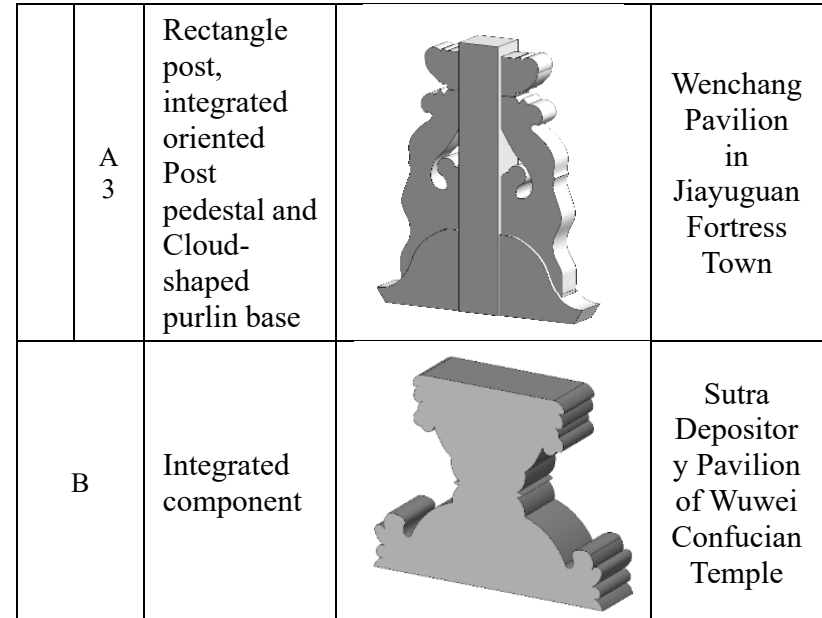

4.1.2 The Inner Purlin-and-Cushion Board-andLongitudinal Tie-Beam Combination

The inner purlin-and-cushion board-and-longitudinal tie-beam combination is the component or component combination under the inner purlin. The typical forms of this combination are the purlin-and-brace-and-dougong-and-inner longitudinal tie-beam combination of the Yingzao Fashi and the purlin-and-cushion board-and-inner longitudinal tie-beam combination which is popular around the official-style buildings in the north China in the Qing dynasty. Far away from the central area, this combination in Hexi Corridor Area is much different from the official one. It can be divided into 5 main types, listed in the following table (L1, L2, L3, L4, L5).

Table. 2 types of the inner purlin-and-cushion board-andlongitudinal tie-beam combination ( $\mathrm{C} 2$ hereinafter)

\begin{tabular}{|c|l|c|}
\hline Type & Components Style Combination & \multicolumn{1}{|c|}{ Style Example } \\
\hline L1 & $\begin{array}{l}\text { Rafter-fixed longitudinal } \\
\text { tie-beam and Purlin and } \\
\text { Brace and Decorated gong } \\
\text { and Inner longitudinal tie- } \\
\text { beam (related to Post) }\end{array}$ & $\begin{array}{l}\text { Three Buddha Hall of } \\
\text { Shengrong Temple in } \\
\text { Minqin }\end{array}$ \\
\hline L2 & $\begin{array}{l}\text { Rafter-fixed longitudinal } \\
\text { tie-beam and Purlin and } \\
\text { Inner longitudinal tie- } \\
\text { beam(related to the main } \\
\text { Beam) }\end{array}$ & $\begin{array}{l}\text { Mhe Great Buddha Hall } \\
\text { Shengrong Temple in } \\
\text { Minqin }\end{array}$ \\
\hline L3 & $\begin{array}{l}\text { Rafter-fixed longitudinal } \\
\text { tie-beam and Purlin and } \\
\text { longitudinal tie- } \\
\text { beam(related to Post/Truss } \\
\text { pier or Cross tie beam } \\
\text { beneath a beam) }\end{array}$ & $\begin{array}{c}\text { Guanghua Building in } \\
\text { Jiayuguan Fortress } \\
\text { Town }\end{array}$ \\
\hline
\end{tabular}

\begin{tabular}{|c|l|c|}
\hline Type & Components Style Combination & Style Example \\
\hline L4 & $\begin{array}{l}\text { Rafter-fixed longitudinal } \\
\text { tie-beam and Purlin and } \\
\text { Inner longitudinal tie-beam } \\
\text { and Sparrow brace }\end{array}$ & $\begin{array}{c}\text { Wenchang Pavilion in } \\
\text { Jiayuguan Fortress } \\
\text { Town }\end{array}$ \\
\hline L5 & $\begin{array}{l}\text { Rafter-fixed longitudinal } \\
\text { tie-beam and Purlin and } \\
\text { Carven board and Inner } \\
\text { longitudinal tie-beam and } \\
\text { Sparrow brace }\end{array}$ & $\begin{array}{c}\text { Sacrifice Hall of } \\
\text { Wenchang Palace in } \\
\text { Wuwei Confucian } \\
\text { Temple }\end{array}$ \\
\hline
\end{tabular}

\subsubsection{The Beam-And-Tie Beam Combination}

The beam-and-tie beam combination is about whether there is a tie beam under the main beam. Of traditional architectural practices, the tie beam is always used under the long-span sevenpurlin beam and not under the others. But in Hexi Corridor Area, it is common that the tie beam is used under each main beam. So according to the use of the tie beam, S1 stands for none-tie beam and $\mathrm{S} 2$ stands for with-tie beam.

Table. 3 types of the beam-and-tie beam combination ( $\mathrm{C} 3$ hereinafter)

\begin{tabular}{|c|c|c|c|}
\hline \multirow{2}{*}{$\begin{array}{c}\text { Typ } \\
\text { e }\end{array}$} & \multirow{2}{*}{$\begin{array}{l}\text { Components } \\
\text { Style } \\
\text { Combination }\end{array}$} & \multicolumn{2}{|c|}{ Style Example } \\
\hline & & Revit Family & Building \\
\hline S1 & $\begin{array}{c}\text { none-tie } \\
\text { beam }\end{array}$ & & $\begin{array}{l}\text { The Great } \\
\text { Buddha } \\
\text { Hall } \\
\text { Shengron } \\
\text { g Temple } \\
\text { in Minqin } \\
\text { County }\end{array}$ \\
\hline S2 & $\begin{array}{l}\text { with-tie } \\
\text { beam }\end{array}$ & & $\begin{array}{c}\text { Sutra } \\
\text { Depositor } \\
\text { y Pavilion } \\
\text { Wuwei } \\
\text { Confucian } \\
\text { Temple }\end{array}$ \\
\hline
\end{tabular}

4.2 Style Characteristics Chronological and Typological Arrangement

The three style characteristics combination of the 16 ancient buildings with clear age identification and good conservation will be arranged according to their age and style characteristics of their timber structure systems.

Table. 4 typological staging results of the 3 combinations

\begin{tabular}{|l|l|c|c|c|l|}
\hline \multicolumn{1}{|c|}{ Building } & \multicolumn{1}{|c|}{ Time/Age } & C1 & C2 & \multicolumn{2}{c|}{ C3 } \\
\cline { 5 - 6 } & & Type & \multicolumn{2}{|c|}{ position } \\
\hline $\begin{array}{l}\text { Three Buddha Hall of Shengrong } \\
\text { Temple }\end{array}$ & $\begin{array}{l}\text { Middle Ming } \\
\text { dynasty }\end{array}$ & A1 & L1 & S1 & Three-purlin beam \\
\hline Main Hall of Xianjiao Temple & 1480 A.D. & A2 & L2 & S1 & Three-purlin beam \\
\hline Main Hall of Leitan Temple & 1555 A.D. & A2 & L2 & S1 & Three-purlin beam \\
\hline $\begin{array}{l}\text { Great Buddha Hall of Shengrong } \\
\text { Temple }\end{array}$ & Late Ming dynasty & A1 & L2 & S1 & Three\&seven-purlin beam \\
\hline Gate Hall of Shengrong Temple & Late Ming dynasty & A2 & L2 & S1 & Three\&five-purlin beam \\
\hline Guanyin Hall of Xilai Temple & Before 1587 A.D. & A2 & L3 & S1 & Three\&five-purlin beam \\
\hline
\end{tabular}




\begin{tabular}{|l|l|c|c|c|l|}
\hline \multicolumn{1}{|c|}{ Building } & \multicolumn{1}{|c|}{ Time/Age } & C1 & C2 & \multicolumn{2}{c|}{ C3 } \\
\cline { 5 - 7 } & & Type & \multicolumn{1}{|c|}{ position } \\
\hline Dacheng Hall of Wuwei Confucian & 1654-1657 A.D. & A1 & L2 & S1 & Three\&five\&six-purlin beam \\
\hline $\begin{array}{l}\text { Sutra Depository Pavilion of } \\
\text { Shengrong Temple }\end{array}$ & 1663 A.D. & A2 & L4 & S1 & Three-purlin beam \\
\hline $\begin{array}{l}\text { Sutra Depository Building of Xilai } \\
\text { Temple }\end{array}$ & 1712 A.D. & B & L4 & S1 & Three-purlin beam \\
\hline North Side Hall of Xilai Temple & 1712 A.D. & A3 & L2 & S1 & Three-purlin beam \\
\hline $\begin{array}{l}\text { Sacrifice Hall of Wenchang Palace in } \\
\text { Wuwei Confucian Temple }\end{array}$ & $\begin{array}{l}\text { Kangxi to } \\
\text { Yongzheng dynasty }\end{array}$ & B & L5 & S1 & Three-purlin beam \\
\hline $\begin{array}{l}\text { Great Buddha Hall of Great Buddha } \\
\text { Temple }\end{array}$ & 1747 A.D. & A3 & L3 & $\begin{array}{c}\text { S1\&S } \\
2\end{array}$ & Three\&five-purlin beam \\
\hline $\begin{array}{l}\text { Sutra Depository Pavilion of Wuwei } \\
\text { Confucian Temple }\end{array}$ & 1772 A.D. & B & L4 & S2 & Three\&five-purlin beam \\
\hline Main Hall of Shanxi Guild Hall & 1883 A.D. & B & L4 & S2 & $\begin{array}{l}\text { Three\&five\&seven-purlin } \\
\text { beam }\end{array}$ \\
\hline Gate Hall of Shanxi Guild Hall & 1883 A.D. & A3 & L4 & S2 & $\begin{array}{l}\text { Three\&five\&seven-purlin } \\
\text { beam }\end{array}$ \\
\hline Main Hall of Minqin Guild Hall & 1892 A.D. & A3 & L4 & S2 & Three-purlin beam \\
\hline
\end{tabular}

Table.5 style characteristics combinations and Revit family modelling of segmental buildings

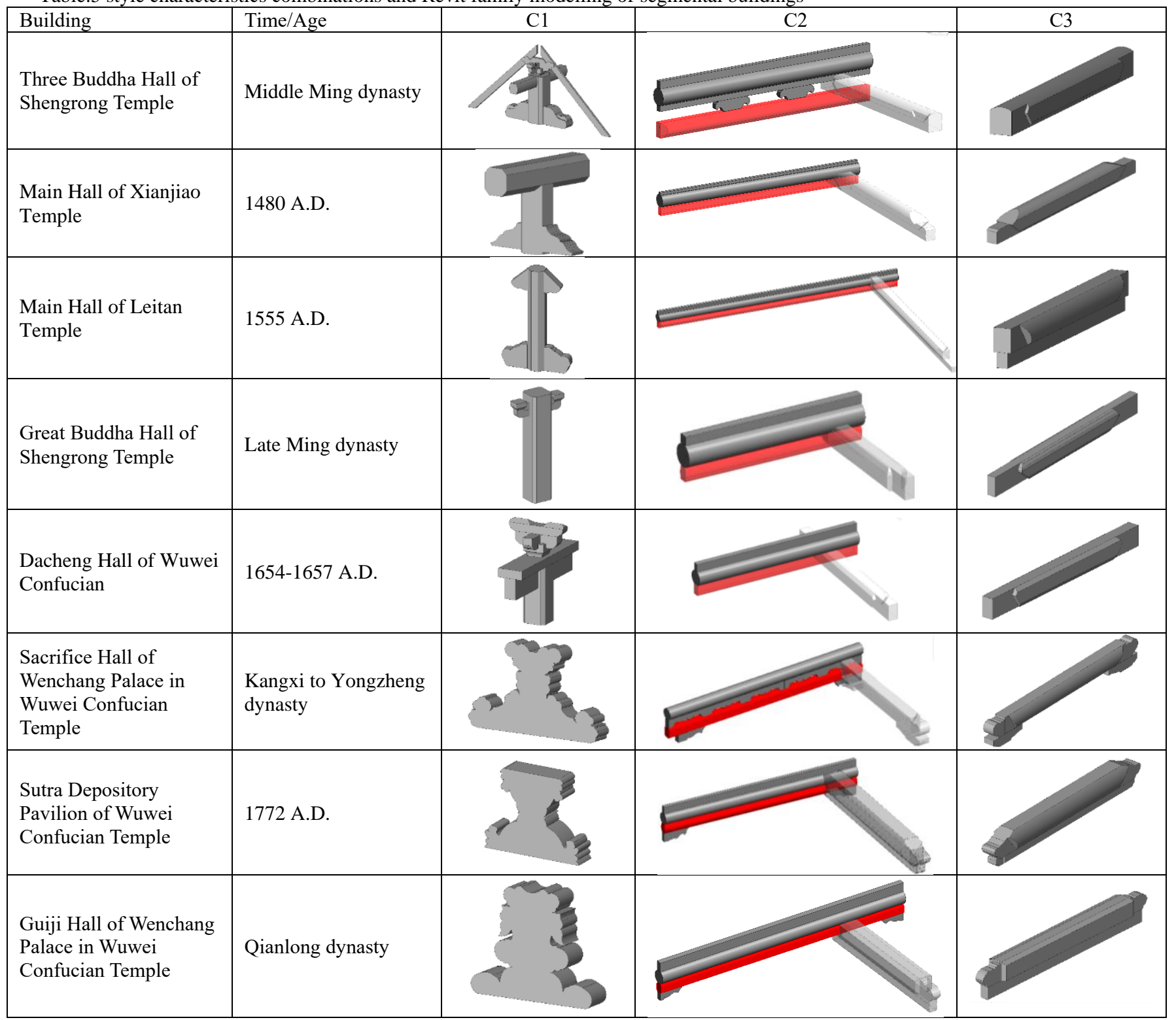




\subsection{Timber Structure System Staging Results and Reason Analysiss}

The significant changes of these three combinations are the use of the tie beams and the transition of the components combination under the ridge purlin from separation to integrity. Of the inner purlin-and-cushion board-and-longitudinal tie-beam combination, the relationships between longitudinal tie-beamand-brace and the main beam are important. The recession and even disappear of the panjian dougong and the appearance of the tie beam result in the evolution of style characteristics, the change of the function of the longitudinal tie-beam combination among the whole structure system, the inevitable result for one structure system to another one.

\subsubsection{The Staging Results Of The Post-And-Post Pedestal} Combination Under the Ridge Purlin

From the table 4 and 5 above, the staging results of $\mathrm{C} 1$ can be divided into 2 main periods, the one from middle Ming dynasty to early Kangxi dynasty of Qing dynasty and the one from late Kangxi dynasty of Qing dynasty to late Qing dynasty.

Type A1 and A2 are the main style characteristics in the former period. But because of the insufficient quantity of the ancient buildings in this period, the priority between A1 and A2 cannot be settled. As we all know, the type A1 inherits many style characteristics in Song and Yuan dynasty and even early Song dynasty. And the type A2 is more associated with the official practices in Ming and Qing dynasty.

Type B and A3 are the main style characteristics in the later period and type B is a more popular one of the two. From the modelling and table, the relationship of the two types is very evident that there is more and more integrated oriented from the one of the north side hall of Xilai temple, the one of the gate hall of Shanxi guild hall to the one of the main hall of Minqin guild hall. So, we can say that type A3 is much possible the early form
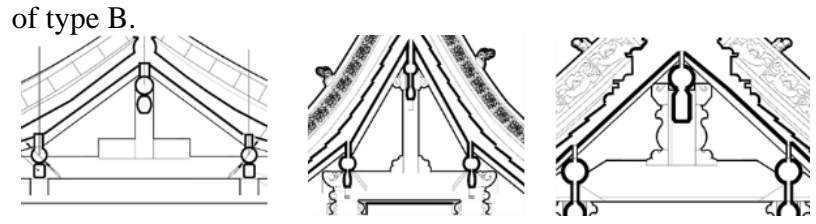

Figure. 7 the change of the style characteristics of type A3
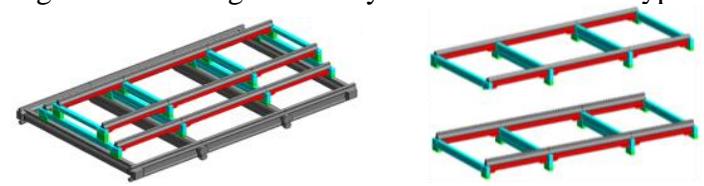

Figure. 8 the Tic-tac-toe Frame structure system

\subsubsection{The Staging Results Of The Inner Purlin-And-Cushion Board-And-Longitudinal Tie-Beam Combination}

The staging results of $\mathrm{C} 2$ can be divided into 3 main periods, the one from middle Ming dynasty to Shunzhi dynasty of Qing dynasty, the one from late Kangxi dynasty to early Qianlong dynasty of Qing dynasty and the one from late Qianlong dynasty of Qing dynasty to late Qing dynasty.

Type L2 is the popular style in the first period with a small amount of type L1 and L3. The recession and even disappear results in the appearance of all the combinations. Type L1 is one useless solution when the panjian dougong under the inner purlin disappeared. Different from the official practice, cushion board instead of panjian dougong, the practice of type L2 just cut down this component, which resulted in the direct contact between inner purlin and longitudinal tie-beam and longitudinal tie-beam connecting with the main beam rather than post or truss beam. Meanwhile, the roof pitch has a special style characteristic as the sayings go"the ridge looks like high mountain and the edge looks like smooth plain", which resulted in a higher roof pitch distance and a higher post. So a higher and isolated post brought a higher instability, which is the result of the following changes.

There are many types existing, L2, L3, L4 and L5, in the second period. For keeping the post stable, the practice to add a brace or sparrow brace under the longitudinal tie-beam was carried out. But because of the lack of large timber, making a contribution to a thinner main beam, the practice to add a tie beam under the main beam was popular. So, the higher post was isolated again. Then the final form of $\mathrm{C} 3$ was confirmed to type L5, adding a cushion board between the longitudinal tie-beam and the brace. Type L4 became the popular practice in the third period. Because of the change from the high post to a short and stout truss beam, the cushion board of type L5 was cut down to return to type L4. As the small components change, the main structure system has made a big evolution, from a vertical structure system to a transverse one, called Tic-tac-toe Frame myself. Of this system, each part has a stable hierarchy, from truss beam to brace-and-tie beam or longitudinal tie-beam-and-main beam to cushion boardand-main beam.

\subsubsection{The Staging Results Of The Beam-And-Tie Beam} Combination

The staging results of $\mathrm{C} 3$ can be divided into 2 main periods. There is no tie beam from middle Ming dynasty to early Qianlong dynasty of Qing dynasty and existing tie beam from late Qianlong dynasty of Qing dynasty to late Qing dynasty.

Table.6 style characteristics combinations staging results

\begin{tabular}{|c|c|c|c|c|}
\hline \multirow[b]{2}{*}{ Staging Results } & \multicolumn{2}{|c|}{$\mathrm{C} 1$} & \multicolumn{2}{|c|}{$\mathrm{C} 2$ and $\mathrm{C} 3$} \\
\hline & $\begin{array}{l}\text { Popular Style } \\
\text { Characteristics }\end{array}$ & Typical Case & $\begin{array}{l}\text { Popular Style } \\
\text { Characteristics }\end{array}$ & Typical Case \\
\hline $\begin{array}{l}\text { Middle Ming dynasty to } \\
\text { Early Kangxi dynasty }\end{array}$ & $\mathrm{A} 1$ and $\mathrm{A} 2$ & & $\mathrm{~L} 2$ and $\mathrm{S} 1$ & \\
\hline $\begin{array}{l}\text { Late Kangxi dynasty to } \\
\text { Early Qianlong dynasty }\end{array}$ & $\mathrm{A} 3$ and $\mathrm{B}$ & & $\begin{array}{l}\mathrm{C} 2 \text { changes } \\
\text { frequently } \\
\mathrm{S} 1 \text { is popular }\end{array}$ & \\
\hline
\end{tabular}




\begin{tabular}{|l|l|c|c|c|}
\hline \multirow{2}{*}{ Staging Results } & \multicolumn{2}{|c|}{ C1 } & \multicolumn{2}{c|}{ C2 and C3 } \\
\cline { 2 - 5 } & $\begin{array}{c}\text { Popular Style } \\
\text { Characteristics }\end{array}$ & Typical Case & $\begin{array}{c}\text { Popular Style } \\
\text { Characteristics }\end{array}$ & Typical Case \\
\hline $\begin{array}{l}\text { Late Qianlong dynasty to } \\
\text { Late Qing dynasty }\end{array}$ & & L4 and S2 & \\
\hline
\end{tabular}

\subsection{The Age Identification Of The Ancient Buildings In Jiayuguan Fortress Town}

At first, the style characteristics of the three combinations of the 4 ancient buildings in Jiayuguan Fortress Town have been listed in the following table.

Table.7 style characteristics of the three combinations of the 4 ancient buildings in Jiayuguan Fortress Town

\begin{tabular}{|c|c|c|c|c|}
\hline Building & C1 & C2 & \multicolumn{2}{|c|}{ C3 } \\
\cline { 4 - 5 } & & Type & Position \\
\hline $\begin{array}{c}\text { Guanghua } \\
\text { Building }\end{array}$ & A3 & L3 & S2 & $\begin{array}{c}\text { three/five/seven- } \\
\text { purlin beam }\end{array}$ \\
\hline $\begin{array}{c}\text { Rouyuan } \\
\text { Building }\end{array}$ & A3 & L3 & S2 & $\begin{array}{c}\text { three/five/seven- } \\
\text { purlin beam }\end{array}$ \\
\hline $\begin{array}{c}\text { Wenchang } \\
\text { Pavilion }\end{array}$ & A3 & L4 & S2 & $\begin{array}{c}\text { three/five/seven- } \\
\text { purlin beam }\end{array}$ \\
\hline $\begin{array}{c}\text { Stage } \\
\text { building }\end{array}$ & A2 & L2 & S1 & $\begin{array}{c}\text { three/fivepurlin } \\
\text { beam }\end{array}$ \\
\hline
\end{tabular}

According to the staging results above, the typological age of the 4 ancient buildings can be judged:

1) The style characteristics form of Guanghua building and Rouyuan building are A3, L3 and S2, belonging to the second period in the table 6 . Because of the use of the tie beam, the typological age is closer to Qianlong dynasty.

2) The style characteristics form of Wenchang pavilion are A3, L4 and S2, belonging to the third period in the table 6 .

3) The style characteristics form of Stage building are A2, L2 and $\mathrm{S} 1$, belonging to the first period in the table 6 .

Meanwhile, there is some literature documentation for confirming a more specific age:

1) There are some records about the historical development of the whole fortress town in Jiayuguan Local Records(嘉峪 关市志)

In the first year of Zhengde dynasty of Ming dynasty (1506 A.D.), the Guanghua building, Rouyuan building, Xuandi temple, official hall, Yi factory and warehouse were repaired. 明正德元年（公元 1506 年）修内城光化楼、柔远楼和

城内的玄帝庙。及官厅、夷厂、仓库等。

In the $31^{\text {st }}$ year of Qianlong dynasty of Qing dynasty (1766

A.D.), the fortress town was massively repaired.

清乾隆三十一年（公元1766 年)，大规模重修关城。

In the $40^{\text {th }}$ year of Qianlong dynasty of Qing dynasty (1775

A.D.), the fortress town was repaired again.

清乾隆四十年（公元1775 年），又重修嘉峪关。

From the $3^{\text {rd }}$ to $4^{\text {th }}$ year of Xianfeng dynasty of Qing dynasty

(1853-1854 A.D.), the fortress town was repaired.

清咸丰三至四年（公元1853-1854 年），重修嘉峪关。

In the $12^{\text {th }}$ year of Tongzhi dynasty of Qing dynasty (1873

A.D.), the fortress town and buildings were repaired and the tablet "Tian Xia Di Yi Guan" was suspended on the Town building.

清同治十二年（公元 1873）年，重修嘉峪关城和楼阁。

“天下第一雄关”匾悬于关楼。

2) In the $54^{\text {th }}$ year of Qianlong dynasty of Qing dynasty (1789 A.D.), a part of the city wall of Jiayuguan Fortress Town collapsed. Decheng (德成) and Lebao (勒保) introduced the damage condition and put forward to rebuild the Town building in a memorial to the emperor (查勘嘉峪关边墙情 形折):

嘉峪关系西陲门户，为外藩朝贺来往通唒，非规模宏 整, 不足以壮观瞻。今查得原设关楼仅止一间, 局面甚为 狭小, 且现在木植糟朽, 城台卷洞闪裂, 今拟量为加高、 展宽, 以资壮丽。

To match up the rebuild advise, Decheng and Lebao put two maps within this memorial, which reflected the town arrangement and architectural forms. There are some verbal contents on the two maps below:

The primary old Town building is one room length, 2.4 zhang (丈) length and width, 3.8 zhang tall, double-hipped roof.

嘉峪关原旧城楼一间，而宽进深俱二丈四尺，通高三 丈八尺，系重簄成造;

The primary old Town building over the west gate is three room length, 4.5 zhang (丈) length and 3 zhang width, 4.8 zhang tall, tribble-hipped roof.

西门原旧城楼一座计三间, 通面宽四丈五尺, 进深三 丈，通高四张八尺，系三重䇾成造;

The primary old Town building over the east gate is one room length, 2.8 zhang (丈) length and width, 3.8 zhang tall, double-hipped roof.

东门原旧城楼一间，面阔进深俱二丈八尺，通高三丈 八尺，系重簷成造。

Plan to change these three buildings to a three-room length, 4.5 zhang length, 3 zhang width, 5 zhang tall and tribble-hipped roof building …...

今拟将城楼三座一律改建三间, 每座通面宽四丈五尺, 进深三丈, 通高五丈, 俱三重䇾底座成造, 关门南北各改 砌砖墙三十五丈，营墩二座，用砖包砌各见方三丈三尺。

There are also some inscribed verbal contents under the ridge purlin in Wenchang pavilion and Stage building:

1) Rebuilt on the $24^{\text {th }}$ of the $8^{\text {th }}$ month of the lunar calendar in the second year of Daoguang dynasty of Qing dynasty. (Wenchang Pavilion)

大清道光二年岁次士午秋八月廿四日卯时重建

2) Rebuilt in the $5^{\text {th }}$ month of the lunar calendar in the $57^{\text {th }}$ year of Qianlong dynasty of Qing dynasty. (Stage building) 大清乾鐆五十七年岁次壬子五月吉日嘉峪关游击袋什 衣经制额外外委士庶军民等重建 


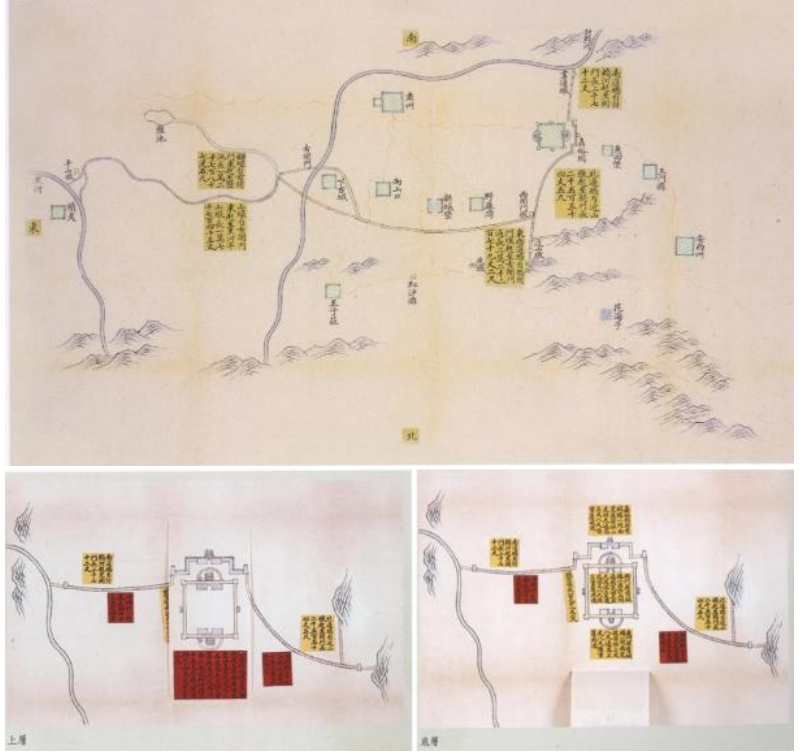

Figure. 9 the two maps within the memorial to the emperor
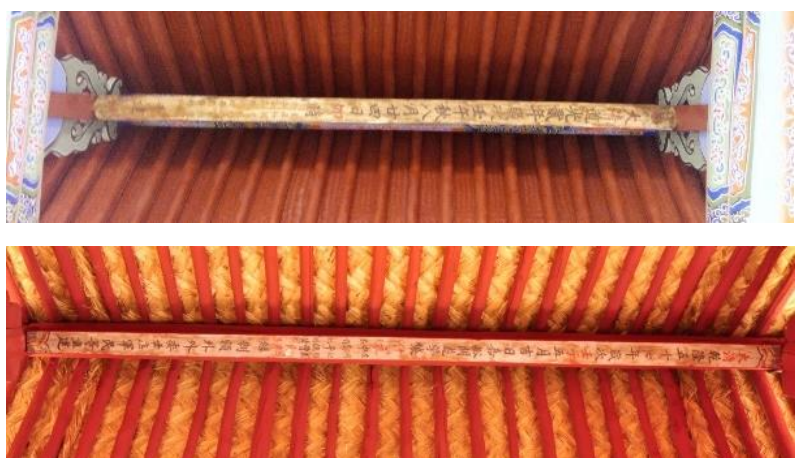

Figure.10 inscribed verbal contents under the ridge purlin in

Wenchang pavilion and Stage building

According to the literature documentation above and the current situation that Guanghua building and Rouyuan building are both three room length, two room width, tribble-hipped roof building, so the real age of the two buildings is just slightly later than the $54^{\text {th }}$ year of Qianlong dynasty.

The inscribed verbal contents under the ridge purlin of Wenchang pavilion proves the accuracy of the typological age from the style characteristics staging results.

According to the inscribed verbal contents under the ridge purlin, the primary main timber structure was reserved among the rebuilt construction in Qianlong dynasty.

\section{CONCLUSION}

From what has been discussed above, HBIM technology application in ancient building can make the model parametric and form a integrated parametric components library. Compared with the past 2D drawings and photos, it is more comprehensive in collection and representation and has more reasonable and uniform classification criteria. Meanwhile, the typological thought is throughout all the modelling process. So with the discussions and researches above, we can draw a conclusion that it is a feasible working process from Structure-and-Type method to Revit family construction to specific research and application.

\section{REFERENCES}

Maurice Murphy, Eugene McGovern, Sara Pavia . Historic building information modelling (HBIM) $[\mathrm{J}]$. Structural Survey . 2009,27 ( 4) : 311-327

S. Logothetis, A. Delinasiou, E. Stylianidis . Building information modelling for cultural heritage:a review . 25th International CIPA Symposium 2015, 31 August to 04 September 2015, Taipei, Taiwan

WU C, WU S, LIU F, et al. Application of BIM on Angkor Monuments : A Case Study on Documentation and Research of the South Outer Gopura in Ta Keo Temple, Angkor Monuments [M]. East Asian Architectural Culture International Conference, 12 to 14 May 2011. Singapore;

Li Shujing. A Preliminary Research about Informatization Survey and Measurement of Historical Buildings based on BIM Technology under the Background of Informatization Survey and Measurement. Doctoral dissertation, 2014, Tianjin University.

Liu Huiyuan. Informationalizing the Architectures in Hexi Corridor based on CGB Technique, Doctoral dissertation, 2013, Tianjin University.

K.Li, S.J.Li, Y.LIU, W.Wang, C.Wu. Coordination between Understanding Historic Buildings and BIM Modelling: A 3DOutput Oriented and typological Data Capture Method.[C]. 25th International CIPA Symposium 2015, 31 August-04 September 2015, Taipei, Taiwan. 